\title{
Possible Implications of Increased Carbon Dioxide Levels and Climate Change for Desert Ecosystems
}

\author{
E. LIOUBIMTSEVA \\ Geography and Planning Department \\ Grand Valley State University \\ Allendale, Michigan 49401, USA
}

\author{
J. M. ADAMS \\ Earth and Environmental Sciences Department \\ Wesleyan University \\ Middletown, Connecticut 06459, USA
}

ABSTRACT / Despite the considerable progress achieved during recent years in quantifying and modeling climatic and ecological processes caused by increasing concentrations of greenhouse gases in the atmosphere, there are still major uncertainties regarding the potential effects of increasing concentrations of either $\mathrm{CO}_{2}$ (carbon dioxide) or future climate change in arid ecosystems. General Circulation Models pre- dict varying patterns of moister or drier conditions in deserts for the next century, but the results of climatic and ecosystem modeling in relation to deserts in a future "greenhouse effect" climate are complex and contradictory. Nevertheless, if deserts do respond more dramatically to global temperature change, as they did during the Holocene and, especially the last interglacial era (130,000 years ago), they might act as globally significant sinks of carbon into soils and vegetation. Some growth chamber experiments have indicated that increased $\mathrm{CO}_{2}$ will significantly affect desert shrubs, whereas other chamber and field experiments suggest that rising levels of atmospheric $\mathrm{CO}_{2}$ may not dramatically affect desert ecosystems, although certain individual species may be strongly favored. It is difficult to make a firm statement whether there are any valid analogs between the climate changes of the past and future climate change induced by greenhouse gases.
It has often been suggested that deserts and semideserts will be one of the most responsive of the world's ecosystem types to the ongoing increase of carbon dioxide $\left(\mathrm{CO}_{2}\right)$ in the atmosphere and associated global climatic changes (Bazzaz 1990; IPCC 2001; Smith and others 2000). Yet despite the considerable progress achieved during recent years in quantifying and modeling climatic and ecological processes caused by increasing concentrations of greenhouse gases in the atmosphere, there are still major uncertainties regarding the potential effects of increasing concentrations of either $\mathrm{CO}_{2}$ or future climate change in arid ecosystems. Evaluation of the role of deserts and semideserts as potential carbon sinks or sources requires further data collection, experimental work, modeling, and interdisciplinary exchange to improve our understanding of climate-ecosystem interactions at various spatial and temporal scales.

Because it has a low organic carbon storage per unit area, the desert biome is often ignored in the biogeochemical literature, and its role in the global system has attracted relatively little interest from scientists. Yet deserts and semideserts are the most extensive of the

KEY WORDS: Carbon dioxide; Desert; Ecosystem; Precipitation; Fertilization; Biomass

Published online January 23, 2004. world's biome types, and the possibility that their extent may drastically alter under future global change [as has been the case under changes in the recent geological past (Petit-Maire and Guo 1996; Lioubimtseva and others 1998)] warrants further consideration of their responsiveness. To the many millions of people who live in desert-margin environments, such questions are certainly of more than academic interest.

The present review has two objectives:

1 To summarize and discuss current understanding by several disciplinary areas of the effects of increasing concentrations of $\mathrm{CO}_{2}$ and accompanying climate changes on temperate and tropical desert and semidesert ecosystems of the world

2 To consider the role that changes in desert extent and desert processes might play in the future carbon cycle

\section{The World's Deserts and Semideserts}

Deserts are created where climatic, topographic, or oceanographic factors exclude moisture-bearing weather systems. In subtropical desert regions, such as the Saharan and Arabian deserts, the southwestern North American semideserts, and the Australian semideserts, aridity is caused by a stable tropical-to-subtropical convection system known as a Hadley Cell. Solar 


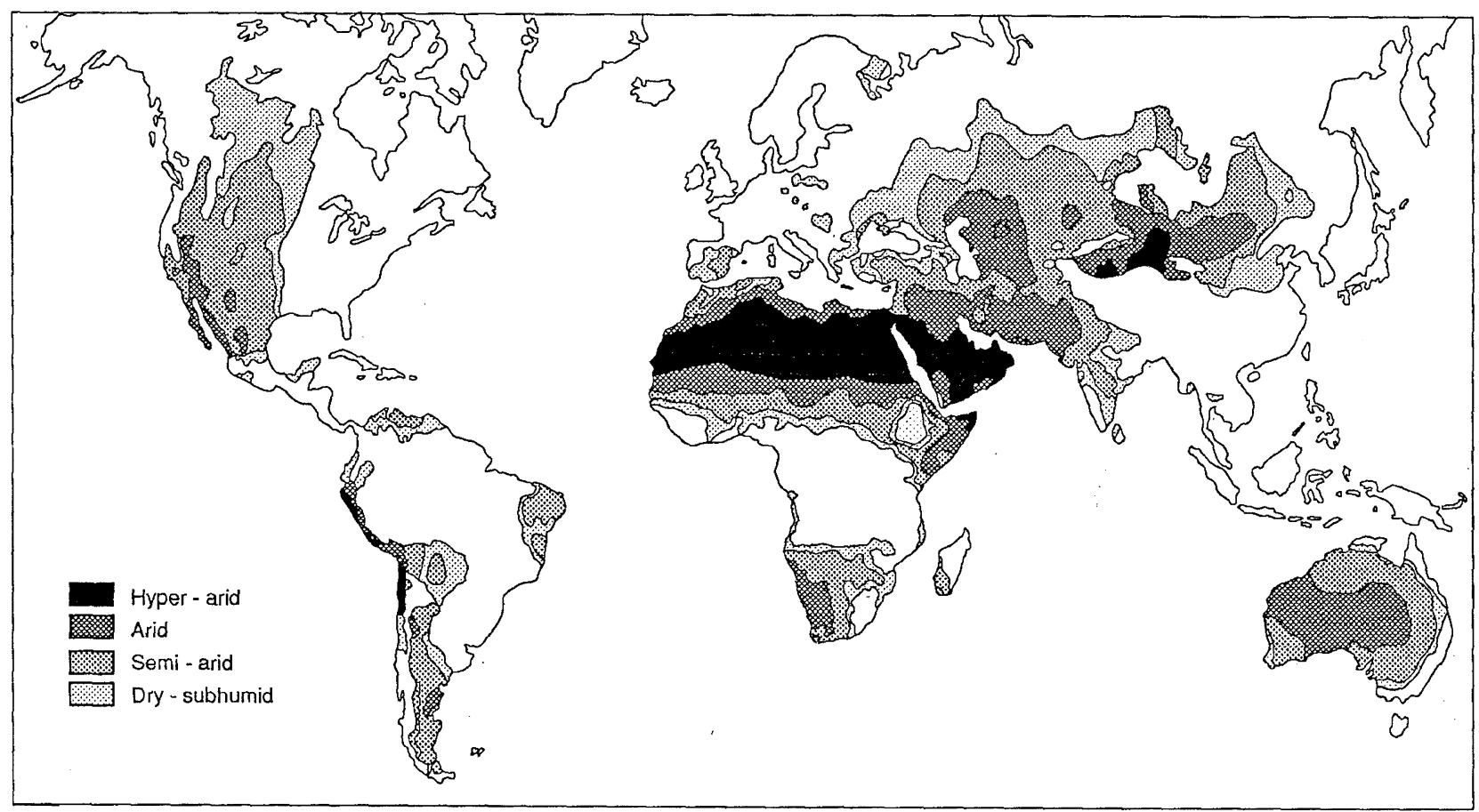

Figure 1. The present-day distribution of deserts and semideserts (after UNEP 1992).

heating of the atmosphere is strongest at the equator, causing air to rise and then cool. The condensation of water in this cooling air forms clouds and an equatorial rainy belt. The rising equatorial air spreads out at high altitude toward the poles and descends in the subtropics at around $30^{\circ}$ north and south. The now-dry air warms due to compression as it descends, creating a consistently warm and dry region in which many of the world's desert and semidesert areas exist. These arid lands are surrounded by narrow semiarid regions. What little rainfall does occur in such regions comes mainly from seasonal monsoons penetrating high- pressure cells from the equator.

At higher latitudes beyond the subtropics, air circulation is controlled more by the rotation of the Earth, and by the temperature contrast between the equator and the poles. In general, this high-latitude pattern is not conducive to creating aridity.

The distance from sources of moisture (continentality) also encourages aridity; arid regions tend to occur near the centers of large landmasses. Because the outer tropical wind belts known as the Trade Winds blow from east to west, deserts and semideserts commonly extend westward to the coasts because these winds lose their moisture in traveling across large continents. This effect produces relatively localized arid zones surrounded by broad semiarid regions.
Mountain ranges prevent moisture-laden air from entering some regions by forcing the air to rise, which makes it cool and causes the water to condense and precipitate. On the lee side, the descending air is warmed and dried adiabatically. Classic examples of arid lands caused by rain shadow effect are semideserts in the western United States and eastern Australia. Likewise, the rain shadow effect of the Andes produces the Argentinean drylands.

Finally, cold ocean currents flowing from the high latitudes toward the equator cause low rates of seasurface evaporation, low precipitation (often as fog and dew due to the lower temperatures), and a low temperature range, reinforcing other climatic factors. This phenomenon affects the western coastal margins of South America, southern Africa, and Australia. For example, the lack of rainfall in the Namib Desert is due to the cold Benguela current impacting the west margin and the failure of easterly rain-bearing winds to penetrate across the African continent (Figure 1).

The balance between precipitation and evapotranspiration is the main factor controlling patterns of vegetation in the deserts. It is important to keep in mind that the amount of rainfall alone is not the absolute control on whether an area is desert. For example, in the semidesert Lake Eyre basin of central Australia, annual precipitation is up to $300 \mathrm{~mm}$, but losses gen- 
Table 1. Climatic categories

\begin{tabular}{llll}
\hline Zone & $\begin{array}{l}\text { Rainfall }^{\mathrm{a}} \\
(\mathrm{mm})\end{array}$ & P PET $^{\mathrm{b}}$ & $\begin{array}{l}\text { Proportion } \\
\text { of the global } \\
\text { land surface }\end{array}$ \\
\hline Hyperarid & $<25$ & $<0.05$ & $7.5 \%$ \\
Arid & $25-200$ & $0.05-0.2$ & $12.1 \%$ \\
Semiarid & $200-500$ & $0.2-0.5$ & $17.7 \%$ \\
Total & & & $37.3 \%$ \\
\hline
\end{tabular}

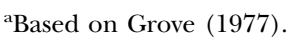

${ }^{\mathrm{b}}$ based on the UN classification (UNEP 1992).

erally exceed $3000 \mathrm{~mm}$ of rainfall equivalent (Kotwicky and Allan 1998). In Arctic environments, which have very low potential evapotranspiration, $300 \mathrm{~mm}$ of precipitation is enough to yield moist tundra vegetation with a continuous dense ground cover. "Arid" zones are defined as those where evapotranspiration exceeds precipitation, although not all arid areas are dry enough or sparsely vegetated enough to be regarded as deserts or semideserts. The widely applied United Nations climate zone classification (UNEP 1992) defines deserts using an aridity index, $P / \mathrm{PET}$, where $P$ is annual precipitation and PET is potential evapotranspiration, which is calculated from meteorological data. In this scheme, the climatic subdivisions are shown in Table 1. According to UNEP (1992), deserts and semideserts together occupy more than one-third of the global land surface.

These subdivisions of aridity can be approximately equated to mean annual precipitation. However, it is crucial to bear in mind that rainfall alone is not the sole control on aridity and to remember that averaging rainfall is misleading, because in arid zones there may be many years when rainfall is zero. A commonly used conversion is that of Grove (1977) (Table 1).

There are considerable variations of desert and semidesert ecosystems on different rock and soil conditions. An overview of the geomorphology of the range of desert and semidesert areas on the planet today can be found in Oberlander (1994).

To many environmental scientists-and to the layman-what actually defines a desert is the vegetation cover rather than the climate. Plant growth in relation to the available moisture is affected by soil type, underlying lithology, slope angle, and aspect. It is also affected by grazing intensity and the history of land use. Although not generally discussed, what constitutes a "desert" or "semidesert" is often confusing because of regional differences in the usage of the words. In North America, the term "desert" is often used to refer to scrublands which are dense enough to sustain commercial ranching and which would probably not even be regarded as semidesert in many regions. However, other areas within the American southwest are indeed sparse enough to be regarded as "semidesert" by most standards. The Australian "deserts" are almost all densely vegetated enough to be regarded as "semideserts" by the standards used in other areas, such as the Sahara. Very few desert landscapes are truly devoid of vegetation; there are usually at least a few scattered plants visible even in the most inhospitable environments. In terms of vegetation, one may approximately define most of the "true" desert areas as having a ground cover of less than $2 \%$, and a semidesert as having a ground cover between about $2 \%$ and $20 \%$.

Hyperarid deserts such as the Sahara only store very small amounts of organic carbon in vegetation. Estimates are few, but Olson and others (1985) put the figure at less than $0.01 \mathrm{~kg} \mathrm{C} / \mathrm{m}^{2}$. Semidesert vegetation can store greater amounts (e.g., $0.6-1.5 \mathrm{~kg} \mathrm{C} / \mathrm{m}^{2}$ ), but this is still very low compared to other biomes.

Carbon can take two main forms in desert and semidesert soils. As in other soils of wetter climates, there is organic carbon, formed from the partial decay of plant and animal materials. This partly consists of complex polyphenolic substances known as humus. Unlike soils of moist climates, desert soils also commonly contain inorganic carbon, as carbonate. Calcium carbonate is often far more abundant in desert soils and, on average, stores about $1-1.5 \mathrm{~kg} \mathrm{C} / \mathrm{m}^{2}$, although its distribution can be spatially very patchy depending on local soil texture and topography. Globally, it is estimated that the calcrete reservoir constitutes about 700-900 gigaton carbon (GtC) (Adams and Post 1998). The source of the carbonate is generally from dust-borne material and/or carbonates already present in soil (Lal and Kimble 2000). The organic and inorganic carbon in soils have very different behaviors in terms of the carbon cycle (Adams and Post 1998; Adams and Lioubimtseva 2002). A decrease in organic carbon generally occurs through oxidation, releasing $\mathrm{CO}_{2}$ into the atmosphere, whereas following a change to a moister climate, calcrete will weather by removing $\mathrm{CO}_{2}$ from the atmosphere into bicarbonate, which is then carried away in water. The magnitude of soil inorganic carbon flux with the atmosphere is difficult to estimate at a local, regional, or global scale (Schlesinger 1995; Lal and Kimble 2000).

The amount of both organic and inorganic carbon in the soils of arid zones is thought to exceed the total reserve of carbon in terrestrial vegetation. According to some authors (e.g., Schlesinger 1985, 1997), arid zone soils contain about $50 \%$ of the amount of organic carbon in soils of the world. According to figures given in the widely used database of Zinke and others (1984), organic carbon in cooler desert and semidesert areas 
Table 2. Values of organic carbon in the desert and semidesert ecosystems

\begin{tabular}{|c|c|c|c|c|c|}
\hline Ecosystem & $P / \mathrm{PET}$ & $\begin{array}{l}\text { Vegetation } \\
\text { carbon } \\
\text { density } \\
\left(\mathrm{kg} / \mathrm{m}^{2}\right)\end{array}$ & Refs. & $\begin{array}{l}\text { Soil } \\
\text { carbon } \\
\text { density } \\
\left(\mathrm{kg} / \mathrm{m}^{2}\right)\end{array}$ & Ref. \\
\hline Hyperarid tropical desert & $<0.05$ & 0.01 & $\begin{array}{r}\text { Olson and others } 1985 ; \\
\text { Ajtai and others } 1979\end{array}$ & $0.1-0.5$ & $\begin{array}{l}\text { Post and others 1982; } \\
\text { Zinke and others 1984; } \\
\text { Schlesinger } 1995\end{array}$ \\
\hline $\begin{array}{l}\text { Hyperarid temperate } \\
\text { desert }\end{array}$ & $<0.5$ & $0.05-0.2$ & $\begin{array}{l}\text { Bazilevich } 1995 \text {, Olson } \\
\text { and others } 1985\end{array}$ & $0.1-1.0$ & $\begin{array}{l}\text { Post and others 1982; } \\
\text { Schlesinger } 1995\end{array}$ \\
\hline Arid tropical desert & $0.05-0.2$ & $0.1-0.2$ & $\begin{array}{r}\text { Olson and others } 1985 \text {; } \\
\text { Ajtai and others } 1979\end{array}$ & $0.3-1$ & $\begin{array}{l}\text { Post and others 1982; } \\
\text { Zinke and others } 1984\end{array}$ \\
\hline Arid temperate desert & $0.05-0.2$ & 0.1 & $\begin{array}{l}\text { Bazilevich 1995; Olson } \\
\text { and others 1985; } \\
\text { Nechaeva, } 1984\end{array}$ & $0.3-3.5$ & $\begin{array}{l}\text { Post and others 1982; } \\
\text { Gladishev and Rodin } \\
\text { 1977; Schlesinger } 1995\end{array}$ \\
\hline $\begin{array}{l}\text { Arid and semiarid tropical } \\
\text { semidesert }\end{array}$ & $0.05-0.5$ & $0.6-1.5$ & $\begin{array}{l}\text { Bazilevich 1995; Olson } \\
\text { and others 1983; 1985; } \\
\text { Nechaeva } 1984\end{array}$ & $0.5-5.5$ & $\begin{array}{l}\text { Zinke and others 1984; } \\
\text { Schlesinger 1995; } \\
\text { Gladishev and Rodin } \\
1977\end{array}$ \\
\hline $\begin{array}{l}\text { Semiarid temperate } \\
\text { semidesert }\end{array}$ & $0.2-0.5$ & $0.6-1.5$ & $\begin{array}{l}\text { Bazilevich 1995; Olson } \\
\text { and others 1985; Ajtai } \\
\text { and others } 1979\end{array}$ & $0.9-3$ & $\begin{array}{l}\text { Post and others 1982; } \\
\text { Zinke and others 1984; } \\
\text { Gladishev and Rodin } \\
1977\end{array}$ \\
\hline $\begin{array}{l}\text { Dry savanna and tropical } \\
\text { steppe }\end{array}$ & $0.2-0.65$ & $2.5-3.5$ & $\begin{array}{r}\text { Olson and others } 1985 ; \\
\text { Ajtai and others } 1979\end{array}$ & $1-5.5$ & $\begin{array}{l}\text { Post and others } 1982 ; \\
\quad \text { Zinke and others } 1984\end{array}$ \\
\hline
\end{tabular}

rivals that in temperate forest soils, with organic carbon storage figures in the range of $6-10 \mathrm{~kg} \mathrm{C} / \mathrm{m}^{2}$. In the more recent database of Batjes and Sombroeck (1997), cool desert soils are assigned a value that is about half of that in the database of Zinke and others (1984). Most of the desert soils data discussed and used in the biogeochemical literature comes from the English-speaking world, especially North America. In those instances where the large African and Asian desert and semidesert areas are included in these assessments, the range of data sources used is limited and there is commonly confusion over the nature of the sources and the ways in which the data were gathered (Adams and Lioubimtseva 2002; Lioubimtseva and Adams 2002).

In general, from a careful study of a range of sources, it seems that desert soils are very poor in organic carbon. Whereas $10 \mathrm{~kg} \mathrm{C} / \mathrm{m}^{2}$ would be common in temperate or tropical forest soils, it is, in fact, rare to find more than $1-2 \mathrm{~kg} \mathrm{C} / \mathrm{m}^{2}$ in a semidesert soil, with less in a desert soil (Schlesinger 1990, 1995; Adams and Lioubimtseva 2002). This reflects the low rate of input of organic material from plants, whose growth rate and overall coverage is low in desert environments. Although the decay rate may be slowed by the dry soil conditions, it is generally rapid enough to cope with the low rate of input of material. Recent estimates suggest that it is somewhere in the range of 61 Gt organic carbon in the world's deserts and semi- deserts (e.g., Adams and Faure 1998). Although desert soils are mostly very poor in organic carbon, local conditions that bring water to the surface or allow it to collect in a hollow can allow increased plant growth and, consequently, soils with much higher organic contents. It is important not to regard local samples from these areas as representative of desert soils in general.

According to estimations of different authors (Bazilevich 1995; Olson and others 1983, 1985; Zinke and others 1984; Lioubimtseva 1999; Lioubimtseva and Adams 2002), overall carbon density in tropical deserts (including vegetation carbon and soil organic carbon) does not exceed $0.01 \mathrm{~kg} / \mathrm{m}^{2}$, in an extreme temperate desert, it is about $0.6 \mathrm{~kg} / \mathrm{m}^{2}$, whereas in temperate semideserts, it amounts to $0.9-1 \mathrm{~kg} / \mathrm{m}^{2}$ (Table 2 ).

\section{Direct $\mathrm{CO}_{2}$ Effects}

Current global models predict that the $\mathrm{CO}_{2}$ level in the atmosphere will double from preindustrial levels by the year 2050 (IPCC 2001). Conceptual models have predicted that water- limited ecosystems such as deserts will respond particularly strongly to elevated $\mathrm{CO}_{2}$. The generalized conceptual model in Figure 2 summarizes the major processes of desert ecosystem responses to elevated $\mathrm{CO}_{2}$ levels and global warming.

For example, Melillo and others (1993) predicted that deserts would increase in annual primary (plant) 


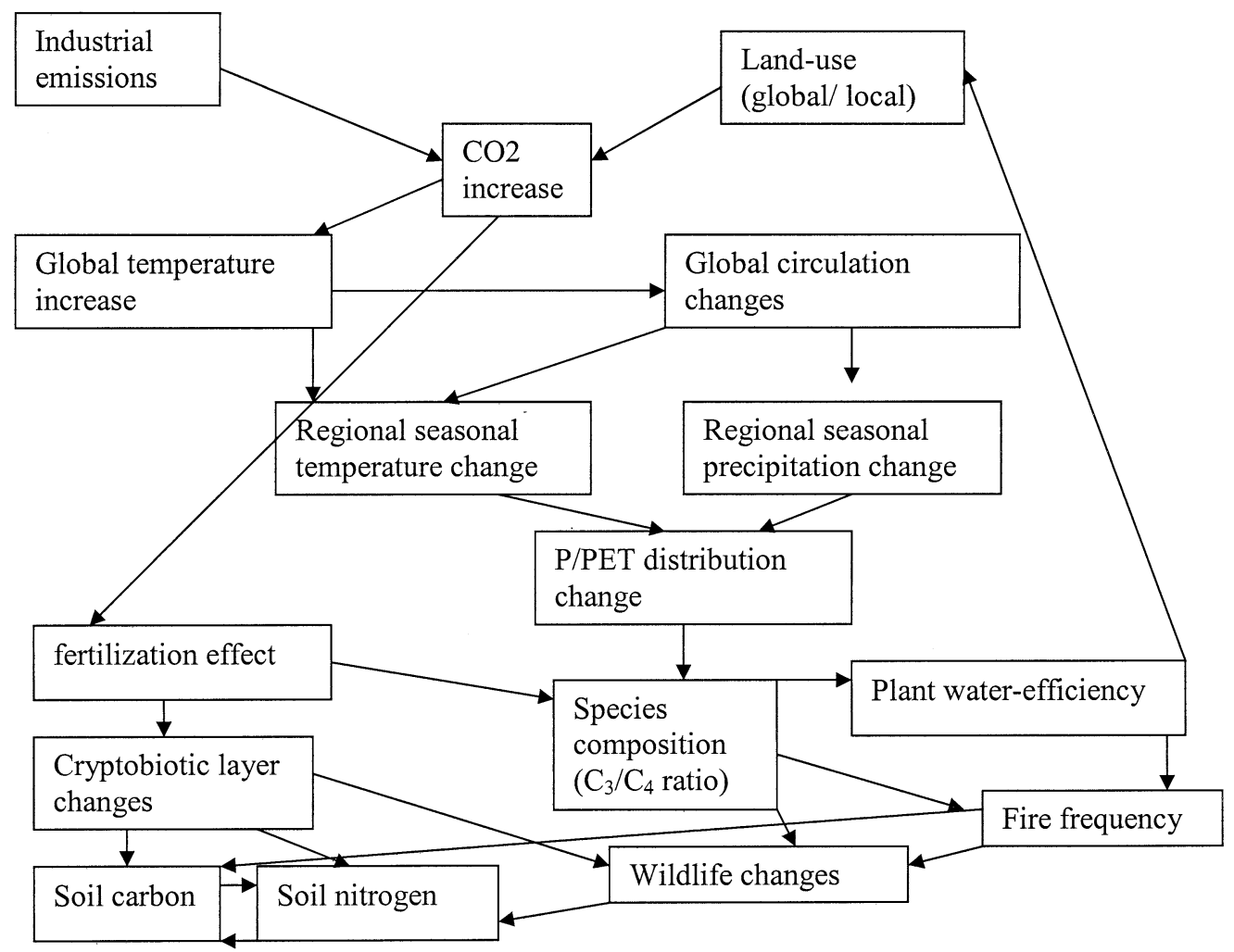

Figure 2. Possible effects of increased $\mathrm{CO}_{2}$ levels on desert ecosystems.

production by $50-70 \%$ in response to a doubling of atmospheric $\mathrm{CO}_{2}$ concentration, whereas most forests will exhibit less than a $20 \%$ increase in production. However, deserts are both water- and nutrient-limited systems (Smith and others 2000), so it is not clear what effects increased growth at high $\mathrm{CO}_{2}$ will have on the already limiting supplies of soil nutrients.

Most of the experimental data testing possible implications of atmospheric $\mathrm{CO}_{2}$ increase deal with forest and grassland ecosystems, especially in North America. However, a significant amount of work has been carried out on $\mathrm{CO}_{2}$-enrichment effects on deserts and desert margins. For example, the Nevada desert Free-Air $\mathrm{CO}_{2}$ Enrichment Facility (Hamerlynck and others 2000; Huxman and Smith 2001; Smith and others 2000), which has been in operation since 1997, is attempting to predict the possible complex ecological and biogeochemical changes in semidesert ecosystems caused by increasing atmospheric $\mathrm{CO}_{2}$. Because experimental equipment and running costs for simulating future $\mathrm{CO}_{2}$ concentrations are so high, few of the countries outside the United States which have arid and semiarid ecosystems have conducted any such work.

In the Nevada FACE experiment in the Mojave Desert, Hamerlynck and others (2000) established 23- m-diameter circular plots on land that contained both semidesert shrubs and a patchy grass cover. Because desert plants generally grow very slowly, it will be important to run the experiment for decades to see how the system responds to raised $\mathrm{CO}_{2}$ (by which time, the ambient $\mathrm{CO}_{2}$ level will be well on its way to meeting the experimental concentration!). Hamerlynck and others (2000) determined that a $52 \%$ increase in the air's $\mathrm{CO}_{2}$ content increased short-term photosynthetic rates in creosote by $100 \%$ and $80 \%$ during the wet and dry seasons, respectively. In addition, because elevated $\mathrm{CO}_{2}$ did not affect rates of stomatal conductance, the wateruse efficiency of this species was similarly enhanced by $100 \%$ and $80 \%$, respectively. However, actual growth rates, rather than short-term photosynthetic efficiency and water use, may not change much under raised $\mathrm{CO}_{2}$. Although some seasonal differences were observed between root growth of the creosote bush Larrea under ambient and raised $\mathrm{CO}_{2}$, the year- averaged root growth rate of both Larrea and Ambrosia was not significantly different between the treatments (Huxman and others 2000). Also, no changes in the aboveground growth rate were observed. However, in contrast to this, closed chamber experiments with Larrea tridentata (creosotebush) and Prosopis (mesquite) shrubs grown under in- 
creased $\mathrm{CO}_{2}$ suggested a significant growth response of the shrubs, with an increase in biomass of these species by $69 \%$ and $55 \%$, respectively (BassiriRad and others 1998).

Another experiment found an increase in seedling survival rates under droughty conditions (Smith and others 2000). In another short-term chamber experiment on various southwestern US semidesert species (BassiriRad and others 1998), there was a doubling in root $\mathrm{N}$ and $\mathrm{P}$ uptake under high $\mathrm{CO}_{2}$ by the grass Bouteloua and a major decrease in $\mathrm{N}$ uptake by the shrub Larrea. Because nutrient limitation is thought to be important in deserts, this unequal response by different species might tend to bring about longer-term changes in plant communities.

The inconsistency in results between closed chamber and free-air fertilization studies and between different species presents a confusing picture in what may happen to semidesert vegetation in the future. One may regard free-air and relatively undisturbed communities at the FACE site as more representative of what will actually happen as ambient $\mathrm{CO}_{2}$ increases, although sometimes chamber experiments might be more representative than free-air studies (C. Koerner personal communication). The upshot is that it is too early to say with any confidence how even the most intensively studied desert shrub communities of the southwestern United States will respond to rising $\mathrm{CO}_{2}$, quite apart from other desert areas.

Also of importance in the results from the FACE site is the fact that a non-native invasive grass, such as Bromus (cheatgrass), responds to $\mathrm{CO}_{2}$ such that it is far more productive than native plants during wet years (Smith and others 2000). Bromus invasions are known to increase the frequency of fires from a 75-100-year cycle to a 4-7-year cycle. These fires are far more intense than those in native vegetation and usually result in a loss of native shrubs. A change from shrubs to grasses under increased $\mathrm{CO}_{2}$ would have a dramatic effect on desert water cycles and wildlife habitat, as well as socio-economic factors (Hamerlynck and others 2000).

Early results from the FACE experiment indicate that both desert shrubs and wet-season semidesert plants such as brome respond especially strongly to increased $\mathrm{CO}_{2}$ during the occasional wet years that correspond to El Niño events. There is greater year-toyear variation in production cycles at elevated $\mathrm{CO}_{2}$, suggesting that this system may become even more episodic and thus, in this sense, more "desertlike" in a future high- $\mathrm{CO}_{2}$ world (Smith and others 2000)

In a study of desert-margin species from the semidesert environment of the Negev, transplanted into greenhouse conditions, species-rich assemblages of winter annual grasses and herbs showed very little biomass response to doubled $\mathrm{CO}_{2}$ but significant changes in tissue quality and species dominance (Gruenzweig and Köerner 2000). However, these latter effects were solely the result of the response of a single legume species. $\mathrm{Had}$ this vigorous species not been included, overall responses would have been minute.

It is often expected that plants which use the more water-efficient and $\mathrm{CO}_{2}$-efficient $\mathrm{C}_{4}$ photosynthetic system will respond less strongly to raised $\mathrm{CO}_{2}$ than plants using the conventional $\mathrm{C}_{3}$ system. Because desert and semidesert ecosystems contain a high proportion of $\mathrm{C}_{4}$ species, one might expect those species to decrease as a proportion of the vegetation relative to increased growth of $\mathrm{C}_{3}$ species. Closed-chamber experiments with $\mathrm{C}_{4}$ and $\mathrm{C}_{3}$ species growing in competition have often supported this view (e.g., Bazazz and Garbutt 1988). In a chamber experiment with various southwestern US desert species, the $\mathrm{C}_{4}$ grass Bouteloua responded with only about half as much increase in biomass (a 25\% increase) as the $\mathrm{C}_{3}$ shrubs Larrea and Prosopsis (BassiriRad and others 1998). However, when intact sods of prairie grassland containing both types of plant were studied in elevated $\mathrm{CO}_{2}$ in the greenhouse, this trend was not found (Hunt and Elliot 1996), and a field experiment revealed the opposite trend: Owensby and others (1993) detected no response in the most important $\mathrm{C}_{3}$ grass (Poa spp. but significant growth stimulation of $\mathrm{C}_{4}$ prairie grasses (Korner 1995). Whether such a situation will "carry over" into more arid environments such as semideserts is a moot question, but these results should be considered as an uncertainty in predicting desert vegetation responses to $\mathrm{CO}_{2}$.

The significance of different photosynthetic pathways in the adaptation of perennial plants to life in extreme desert environment is still debated (Whitford 2002). In the hot deserts of North America, one or more species of $\mathrm{C}_{3}$ plants (i.e., creosotebush, Larrea tridentata) dominate the plant communities. According to the general physiological characteristics of such plants, the $\mathrm{C}_{3}$ plants should be the least adapted to hot desert environments because they are less water efficient than $\mathrm{C}_{4}$ plants and have a lower optimum temperature and lower rates of photosynthesis. $\mathrm{C}_{3}$ plants light saturate at low light intensities. These properties of $\mathrm{C}_{3}$ plants affect many of the growth and morphological characteristics of $\mathrm{C}_{3}$ plants that are successful in the hot temperate desert (Table 3 ).

Among other effects noted in arid-land plants exposed to increased $\mathrm{CO}_{2}$, it appears that increasing the atmospheric $\mathrm{CO}_{2}$ concentration can reduce the impact of salinity on plant growth (Poorter and Perez-Soba 
Table 3. Comparison of the general characteristics of $\mathrm{C}_{3}$ and $\mathrm{C}_{4}$ plants

\begin{tabular}{lll}
\hline Characteristic & $\mathrm{C}_{3}$ plants & $\mathrm{C}_{4}$ plants \\
\hline Light saturation & $1 / 4$ Full sunlight & Higher than sunlight \\
Optimum temperature & $\sim 25^{\circ} \mathrm{C}$ & $\sim 45^{\circ} \mathrm{C}$ \\
Water loss rate $\left(\mathrm{g} \mathrm{H}_{2} \mathrm{O} / \mathrm{g} \mathrm{C}\right.$ fixed) & $\sim 600$ & $\sim 250$ \\
Photosynthetic rate $\left(\mathrm{mg} \mathrm{CO} / \mathrm{dm}^{2}\right.$ leaf $\left.\mathrm{hr}\right)$ & 25 & 60 \\
\hline
\end{tabular}

Source; Adapted from Whitford (2002).

2001). This could have implications for crop growth in desert-marginal areas, favoring greater productivity, and perhaps increase productivity and biomass of natural desert vegetation and soil organic matter.

From the limited amount of experimental information on responses of desert and arid- land plants to increased $\mathrm{CO}_{2}$, it seems that most of the preconceptions have to some extent been supported and to some extent challenged. Some experiments suggest that either because of nutrient limitations or their innately low growth rate, desert and semidesert plants may hardly be able to respond to high $\mathrm{CO}_{2}$ in terms of growth rate and biomass. Other experiments suggest a strong response by the very same species of droughttolerators. In certain experiments, there is a disproportionate response to $\mathrm{CO}_{2}$ by particular plant "types" or even by certain individual species which apparently arbitrarily show a very large response when most others barely respond. The general forecast favoring a stronger response of $\mathrm{C}_{3}$ plants over $\mathrm{C}_{4}$ species is tentatively supported, but is subject to uncertainty given the contradictory results from prairie species. The amount of idiosyncrasy in responses seen in all of these various experiments would seem to make the prediction of $\mathrm{CO}_{2}$ effects on any particular desert region (or deserts in general) a rather risky business, for it may vary greatly with the detailed community assemblage and perhaps other local factors such as soil variations and herbivory.

Another factor which should be borne in mind is that many of the free-air $\mathrm{CO}_{2}$ experiments that have been run in nondesert biomes (e.g., temperate forests) for more than a few years show a decline or even a disappearance of the effects of $\mathrm{CO}_{2}$ on plant growth rates. It is unclear what this might mean in terms of biomass and species composition as the plant community reaches a rough equilibrium in the longer term. The Nevada desert $\mathrm{CO}_{2}$ experiment has not been run for as long as certain other experiments, and because desert plants tend to be slow growing, the time taken to reach equilibrium to higher $\mathrm{CO}_{2}$ levels (and decrease in growth rate?) may be even longer. Even if growth rates remain high, there is no certainty that this will translate into greater vegetation biomass beyond a boost in the earliest years, because nutrient limitation may begin to dominate.

\section{Future Effects of Global Warming on Deserts}

Beyond the direct effects of increasing $\mathrm{CO}_{2}$ on plant growth, there are the indirect effects that greenhouse gases will tend to exert by changing the climate. The general circulation models (GCMs) that are used to forecast global climate change over the next 50-100 years are undergoing rapid development, but there is still considerable disagreement between different models in terms of the amount and distribution of warming and (more especially) the changes in precipitation that will occur.

The scenarios projected for deserts under global warming are quite variable, depending on the model. With the projected global temperature increase due to the greenhouse effect, it is generally thought that the global hydrological cycle will also intensify, giving moister climates, on average. One predicted effect of global warming associated with the observed increase of $\mathrm{CO}_{2}$ is an increase of precipitation in some regions caused by a shift in monsoonal circulation (Street- Perrot and others 1990; Liu and others 1995; Petit-Maire and Guo 1996).

Some GCMs suggest that particular desert regions will become moister on average, whereas others suggest drier conditions. However, the detailed distribution of moistening or drying varies markedly from one model to another. A desert region that one model suggests will become significantly moister often becomes significantly drier or does not change in another model projection. A summary of GCM models in the early 1990s (IPCC 2001) suggested that that global precipitation could increase by anywhere between $7 \%$ and $15 \%$, whereas global evapotranspiration could increase between $5 \%$ and $10 \%$ due to the warmer temperatures, partly offsetting the increased rainfall. The more recent IPCC summary of GCM models (IPCC 2001) reaches similar conclusions; it appears that uncertainty is not decreasing. GCMs tend to forecast that in mid-continent regions, evapotranspiration will increase more than precipitation and there will be the potential for more severe, longer-lasting droughts in these areas. 
To translate from a climate prediction to a prediction of change in vegetation cover, it is necessary to use a vegetation-climate scheme. Such a scheme, of which there are several in current use in global change modeling, defines the climatic boundaries of each vegetation type and allows vegetation distribution to be predicted from a GCM's climate output. It is necessary to bear in mind that such schemes differ from one another, and being simplifications, all are, to some extent, imperfect in predicting even the present-day world's vegetation from current climates. Furthermore, some forecasts of vegetation under future greenhouse warming include more complex vegetation models that incorporate direct $\mathrm{CO}_{2}$ effects as well as climate. On the basis of the results of $\mathrm{CO}_{2}$ fertilization experiments mentioned in the previous section, there are grounds for considerable skepticism that the direct effects of $\mathrm{CO}_{2}$ on arid-land vegetation can be adequately modeled at present.

In terms of modeling future climates, the most sophisticated research area includes the incorporation of ground-cover feedbacks from vegetation affecting the global climate. Thus, when predicting the effect of $\mathrm{CO}_{2}$ on climate, the ground cover, canopy density, and other parameters of vegetation are included in the GCM model. This has been found to significantly alter the modeled climate, due mainly to albedo (reflectivity) effects and alteration of moisture supply to the atmosphere from evapotranspiration. In the most sophisticated modeling studies, there is a process of iteration between climate and vegetation cover (Zheng and others 1999; Claussen and others 1999). In earlier versions of these iterative models, the GCM climate alters in response to the presently existing ground cover, and using a vegetation model, the "new" vegetation cover that corresponds to the predicted climate is calculated. Using the new- vegetation-cover distribution, the GCM is run again, and so on until the vegetation-climate system stops responding. In more recent versions, there is no need to stop the model to run it again with a new-vegetation distribution; the vegetation and climate can alter continuously and interactively as part of the model (Zheng, personal communication 2002).

Modeling future climates using such vegetation feedbacks is probably still at an early stage of its development, but, for the most part, incorporation of this factor in a GCM run increases the responsiveness of the modeled climate to increased greenhouse gas levels. This includes both desert and semidesert regions, as well as areas of moister climate. Interestingly, some of the most important vegetation-climate feedbacks which affect desert regions occur not within these regions themselves, but in adjacent forested and wooded areas that send moist air across to fall as rain. For example, in North Africa, an initial increase in the amount of forest vegetation in West Africa could result in a substantial increase in rainfall over the Sahel and Sahara due to the monsoon moving further north (Bras, personal communication). It also appears that in desert-marginal regions, internally generated natural climate fluctuations in the present climate (e.g., El Niño events) are amplified by vegetation feedbacks (Zeng and others 1999). The apparent success of GCMs in better explaining climate switches in the Sahara in the past when they incorporate vegetation feedbacks (Claussen and others 1999) also tends to argue for their importance in future climates in desert regions.

An additional factor that needs to be considered in GCM simulations of both global and regional climates is the role of the dust blown into the atmosphere from arid lands (Coudé-Goussen 1991; Miller and Tegen 1998; Guieu and others 2002). Dust tends to cool the earth by reflecting sunlight back into space, and it decreases rainfall by suppressing atmospheric convection. GCM simulations of future climate which include changes in dust loading tend to yield different results from those that do not, and the incorporation of iterative feedbacks among simulated future climate, vegetation cover, and dust flux from changes in vegetation cover tends to further amplify the changes in arid-land climates (Zender and others 1999). In general, it seems that following an initial increase in rainfall over arid areas, dust flux decreases due to increased stabilizing vegetation cover and moister soils. This decrease in dust flux tends to cause rainfall to increase further. However, at present, the incorporation of dust feedbacks in models is in its early stages. One may consider in a general way what its implications might be. Although the world is generally forecast to become moister as greenhouse gas levels increase, this effect is patchy and, according to certain models, some desert areas may become drier. In this case, increased dust flux may increase aridity and also suppress rainfall outside the desert areas themselves.

In general, the GCM results available by the mid1990s suggest that there will be relatively little change in desert (arid) communities over the next 50-100 years. One study, which used four GCM climate projections, concluded that deserts were the most stable of the 16 vegetation types considered (IPCC 1995, WG II, Chapter 3). It was estimated that only $59-66 \%$ of all combined vegetation types for the world would remain in the same category, whereas $82-92 \%$ of existing deserts would retain this classification. The more advanced transient GCMs, such as the Hadley Center models (HADCM2 and HADCM3) and Canadian Climate Centre model (CGCM1), include a fully dynamic 
three-dimensional (3-D) ocean and are run from the 1800s to the present using observing $\mathrm{CO}_{2}$ increases and into the future using IPCC predictions of future greenhouse gas concentrations (Kattenberg and others 1996 ; Hulme 1999). These scenarios also show considerable disagreement in attempting to predict annual precipitation in most of the world's desert regions by 2080 (Hulme 1999). HADCM2 scenarios (both HDCM2GHG (a greenhouse-gas-only scenario) and HADCM2SUL (a sulfate scenario that takes into account the negative influence from sulfate aerosols) tend to show significant increases in precipitation (20$40 \%$ ) in parts of the Sahara and Arabian peninsulas, East Africa, Central Asia, and the American West and a significant decrease of precipitation in Central Australia, the Sahel, and the Mediterranean coast of Africa. The HADCM3 experiment showed slightly different patterns of changes in precipitation regimes over the same areas (Hulme and others 2000; New and others 2000). Over much of the tropics and subtropics, the range of precipitation changes exceeds $30 \%$ in the ensemble mean. The regions of largest range include most of the major desert and semidesert regions, which are potentially the most vulnerable to reduction in precipitation and where long-term trends are especially difficult to predict because of the strong natural variability of precipitation (Hulme and others 2000, 2001).

Biogeography models such as MAPSS (Mapped Atmosphere-Plant-Soil System) and BIOME-3 are used to simulate vegetation zonal changes under various climate change scenarios (VEMAP 1995; IPCC 2001). One of the recent vegetation modeling experiments by Bachelet and others (2001) used both the static model MAPSS and a dynamic model MC1 to simulate changes in potential equilibrium vegetation distribution and its associated carbon pools throughout the conterminous United States under seven GCM scenarios. Simulations for the western United States show 60\% or greater reduction in the area of deserts under HADCM2SUL, HADCM2GHG, and CGM1 (Bachelet and others 2001). However, a further rise in temperature might cause the return and further intensification of aridity. Also, the area subjected to droughts appears to increase linearly with respect to temperature change. The increase of aridity and the expansion of desert zones forecast by warmer climatic scenarios will result in net losses of carbon in vegetation in soils in many parts of the world. The results of GCMs in relation to deserts in a future "greenhouse effect" climate are complex and contradictory. Hopefully, the results of a new generation of GCMs incorporating coupled ocean and land circulation and land surface feedbacks and dust flux effects will give a more consistent picture.

\section{Past Climate Switches in Deserts}

Although GCM projections for the future are hypothetical, a range of geologic indicators shows that the drastic changes in desert climate have actually occurred in the recent geological past. The climate of the present-day deserts and semideserts is known to have changed at various temporal and spatial scales. Pleistocene climate variations had a marked effect on many presently arid zones. During the Pleistocene glacials, aridity increased, as moisture was locked up in the ice, and winds were stronger, which increased evaporation rates. During interglacials, there were periods much wetter than the present. Such variation is well documented even in areas far away from glaciated regions, such as in Africa, the Arabian peninsula, and central Australia (Petit-Maire and Guo 1996; Sanlaville 1992; Claussen 1998 ; Nanson and others 1992).

Available palaeohydrological (lake level, runoff), paleozoological, pollen, and paleopedological data from various tropical regions of the world suggest that climatic conditions of the Last Interglacial (130,000-125,000 years ago) were much wetter than now or even than at the Holocene (Nanson and others 1992; Lioubimtseva and others 1998). The global climatic optimum of the Last Interglacial was characterized by much more humid conditions compared to the present and relatively high concentrations of $\mathrm{CO}_{2}$ in the atmosphere (300-320 ppmv around 130,000 ka), close to the present-day concentrations (Barnola and others 1991; Mudelsee 2001).

During the Last Glacial Maximum (LGM) about 21,000 years ago, extreme deserts occupied far greater areas than at present (Figure 3). In the equatorial regions, mean annual precipitation decreased by at least $1000 \mathrm{~mm}$ compared to the present and the $100-\mathrm{mm}$ isohyet shifted south to $13-14^{\circ} \mathrm{N}$ in Africa and on the Arabian and Indostan peninsulas (Petit-Maire and Guo 1996; Sanlaville 1992; Abell and others 1996). During that period, semidesert and dry savanna landscapes spread into the present-day zone of humid tropical forests (Bonnefille and others 1990). Cold (and cool) deserts and semideserts prevailed in Central and Eastern Asia, both northward and southward of the present-day desert zone. On the Loess plateau of China, subtropical subhumid forests gave way to cold dry steppes with considerable aeolian dust (loess) accumulation (Liu and others 1995). Rapid loess accumulation (more than $0.3 \mathrm{~mm}$ per year) occurred also in southern Uzbekistan and Tadjikistan (Lioubimtseva 1999). In Australia, the present semidesert area was replaced by extreme desert that expanded to cover much of the continent. However, despite the marked trend toward 


\section{Last Glacial Maximum $\left(18,000{ }^{14} \mathrm{C}\right.$ years ago)}

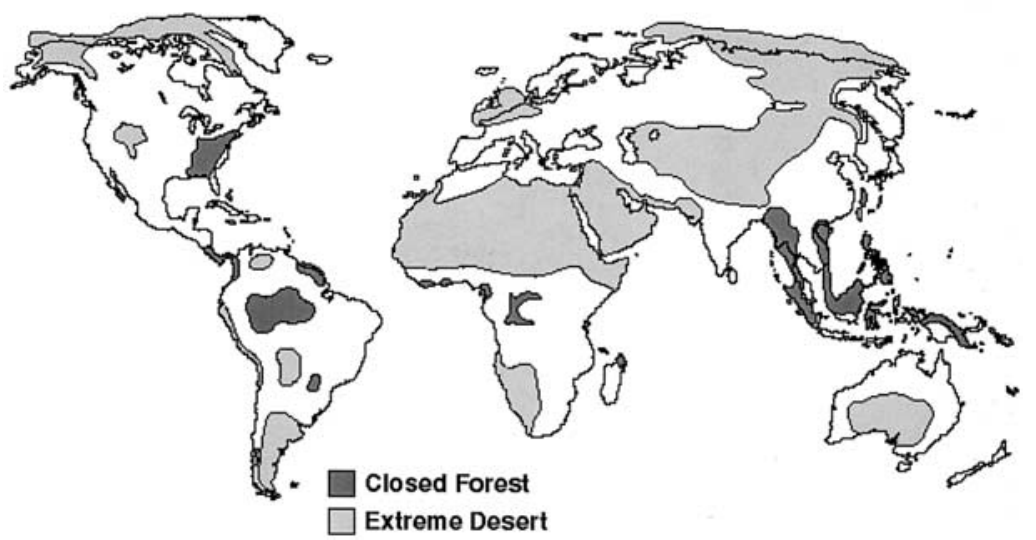

Figure 3. Distribution of desert ecosystems during the Last Glacial Maximum. greater aridity, not everywhere in the Last Glacial Maximum world was drier than present. Because of southward shifts in rain-bearing wind belts, the semidesert extent in the southwestern United States was less than at present, and part of the northwestern Sahara was somewhat moister (Rognon 1987; Thompson and others 1993).

In contrast, the early to middle Holocene world around 9000-4000 years ago had much less desert in certain areas. For much of this time, the Sahara as a desert had virtually disappeared and was covered by a mosaic of scrub, grasslands, and woodlands populated with giraffes, elephants, and other animals that now only survive far to the south. However, this generally moist period seems to have been punctuated by more arid phases (some of which were about as dry at present) often lasting hundreds of years. In the Sahara, the climatic optimum of 8500-6500 years ago resulted in an almost 50-fold increase in precipitation (by 200-300 $\mathrm{mm}$ ) compared to the present (Petit-Maire and others 1998). The SaharoSahelian boundary shifted at those times to $22-23^{\circ} \mathrm{N}$, that is by $500 \mathrm{~km}$ to the north compared to its present-day position and by $1000 \mathrm{~km}$ compared to the LGM situation (Petit-Maire and Guo 1998). A considerable increase in precipitation occurred on the Arabian peninsula and in Rajasthan, resulting in the total disappearance of arid landscapes and in the spread of savanna vegetation on the Arabian peninsula and in Central Asia (Sanlaville 1992; Tarasov 1992).

Our estimations, based on pollen spectra and other paleoclimatic data, showed that during the early part of the Last Interglacial (130,000-125,000 years ago), the biota carbon stored in the vegetation and soil of the present-day deserts of Northern Africa and Central Asia could have been between 257 and 360 Gt (Lioubimtseva and others 1998; Lioubimtseva, 1999). However, we do not know if the increase in humidity caused by the shift of monsoonal circulation was only one factor in this vegetation change in this currently desert zone or whether a fertilization effect caused by higher concentrations of $\mathrm{CO}_{2} 125,000$ years ago could have also trigged changes in the vegetation cover of this area (although this seems unlikely because $\mathrm{CO}_{2}$ levels do not seem to have been any higher than they are at present).

On the other hand, during the Last Glacial Maximum, total carbon storage in the landscapes of the Afro-Asia desert belt seems likely to have been somewhere between 70 and 93 Gt. The total carbon storage in the deserts of Northern Africa and Asia during the Holocene Optimum was between 218 and 283 Gt (recalculated from the work Lioubimtseva and others (1998, 1999). For comparison, the present-day total content of organic carbon in desert and semidesert landscapes of this zone is about 120-160 Gt (Table 4).

If we consider these palaeoenvironmental changes in terms of carbon storage variations, they would mean that the increase in Sahara-Gobi biota carbon from the Last Glacial Maximum to the Holocene Climatic Optimum amounted to about $200 \mathrm{Gt}$ (almost three times). Its decrease from the Last Interglacial to the LGM was even higher: about 240-270 Gt. The carbon reservoir of the Afro-Asian desert belt has considerably increased from the Last Glacial Maximum to the Holocene Optimum. After the last humid phase, a rapid decrease in rainfall seems to culminate in natural aridization and human-induced desertification. Careful study is still needed to assess the biomass decrease from the Holocene Optimum to the present with more accuracy, but it is assumed here that it could decrease about one-half or more (Lioubimtseva 1999). 
Table 4. The palaeoeolandscapes of the Sahara-Gobi desert area (recalculated from Lioubimtseva and others $(1998,1999)$

\begin{tabular}{|c|c|c|c|c|c|c|}
\hline \multirow[b]{3}{*}{ Ecosystem } & \multicolumn{6}{|c|}{ Time interval } \\
\hline & \multicolumn{2}{|c|}{ Last Interglacial } & \multirow[b]{2}{*}{$\begin{array}{l}\text { Area } \\
\left(\times 10^{6}\right. \\
\mathrm{km}^{2}\end{array}$} & \multicolumn{2}{|c|}{ Last Glacial Maximum } & \multirow{2}{*}{$\begin{array}{l}\text { Holocene } \\
\text { Optimum }\end{array}$} \\
\hline & $\begin{array}{l}\text { Area } \\
\left(\times 10^{6}\right) \\
\mathrm{km}^{2}\end{array}$ & $\begin{array}{l}\text { Totals } \\
\text { of carbon } \\
\text { storage, } \\
(\mathrm{Gt})\end{array}$ & & $\begin{array}{l}\text { Totals } \\
\text { of carbon } \\
\text { storage } \\
\text { (Gt) }\end{array}$ & $\begin{array}{l}\text { Area } \\
\left(\times 10^{6}\right. \\
\left.\mathrm{km}^{2}\right)\end{array}$ & \\
\hline Extra-arid tropical desert & - & - & 0.74 & $0.1-0.5$ & - & - \\
\hline Arid tropical desert & & & 9.97 & $6-12$ & 2.1 & $1-3$ \\
\hline Arid and semiarid tropical semidesert & 6.6 & $40-53$ & 1.07 & $6-8$ & 1.1 & $6-9$ \\
\hline Dry savanna and tropical steppe & - & - & 1.14 & $14-18$ & 6.9 & $86-107$ \\
\hline Subhumid tree savanna and open woodlands & 2.82 & $35-44$ & - & - & $3.0-5.0$ & $38-47$ \\
\hline Semiarid Mediterranean woodland & 2.42 & $24-36$ & 1.05 & $12-17$ & 0.76 & $9-12$ \\
\hline Tropical and subtropical forest & 2.19 & $52.7-60.98$ & - & - & - & - \\
\hline Temperate steppe & 3.9 & $80.34-101.4$ & 0.93 & 20.93-26.04 & 1.85 & $37-51.8$ \\
\hline Arid temperate desert & - & - & 1.83 & $5.67-6.59$ & 0.04 & $0.12-0.14$ \\
\hline Temperate and mountain mixed forest-steppe & $0.77-9$ & $23.7-28.44$ & - & - & 1.25 & $28.75-37.5$ \\
\hline Mountain tundra-steppe and steppe & - & - & 0.29 & $4.51-6.15$ & - & - \\
\hline Totals (Gt C) & 18.03 & $\begin{array}{l}\text { MIN } 256.45 \\
\text { MAX } 359.59\end{array}$ & 17.54 & $\begin{array}{l}\text { MIN 70.61 } \\
\text { MAX 93.08 }\end{array}$ & 17.89 & $\begin{array}{l}\text { MIN } 218.39 \\
\text { MAX } 283.35\end{array}$ \\
\hline
\end{tabular}

Such results of order-of-magnitude biomass changes in arid zones are important in understanding the behavior of the carbon cycle since the last interglacial. The general increase in the extent of deserts at the expense of arborescent and tall-grass vegetation during the LGM in tropical areas might have been driven not only by cooling or by drier conditions but also partly by the lowering of the atmospheric $\mathrm{CO}_{2}$, although as one may infer from the previous section on direct $\mathrm{CO}_{2}$ effects, this is a topic fraught with uncertainty.

The mechanisms causing these drastic changes in desert environments are somewhat unclear. Possible mechanisms include runaway feedbacks involving the dust content of the atmosphere, and the albedo of the land surface, amplifying an initial random change such as a run of unsusally dry or wet years so that the regional or global climate system "flips" into a new state. Some of these shifts appear linked to orbital variations in the ratio of summer to winter sunlight (known as Milankovitch rhythms). For example, the tendency toward moister conditions in the Sahara in the early and middle Holocene seems to have been brought about largely by the greaterthan-present summer solar radiation intensity, driving a stronger monsoon. The change toward drier climates in the Sahara after around 5000 years ago would also seem to be the inevitable result of a gradual decrease in summer sunlight. A modeling experiment by Claussen and others (1999) suggests that a gradual decline in summer sunlight could indeed bring about a sudden change in climate and vegetation, due to feedbacks involving the vegetation once a critical point had been reached. Nevertheless, many sudden changes and reversals (such as those which apparently occurred in the Sahara several times during the Holocene moist phase) cannot be attributed to Milankovitch changes and must be due to random background changes becoming drastically amplified. The success of GCMs in simulating the effects of Milankovitch variations in sunlight on Holocene precipitation changes in the Sahara suggests that an analogy between the early Holocene and the future greenhouse world would not be valid.

The unstable history of the Sahara and other parts of the northern monsoon system seem to emphasize the future potential for dramatic sudden changes in deserts. Desert regions may have a greater sensitivity to $\mathrm{CO}_{2}$-induced climate change than GCMs predict. Also, there is the constant possibility of natural background changes that could occur at any time regardless of what we do to the climate system.

\section{Desertification and Climate Change}

Changes in the carbon budget in the desert ecosystems are, however, related not only to the effects of increasing atmospheric $\mathrm{CO}_{2}$ concentrations, caused by the human impact all over the world. Local and re- 
gional effects of agricultural land use, such as anthropogenic desertification, is another important factor altering the carbon budget of arid and semiarid zones. Desertification implies "land degradation in arid, semiarid and dry sub-humid areas resulting from various factors including climatic variations and human activities" (UNEP 1992; UNCCD 2001). This complex phenomenon includes processes arising from human activities and habitation patterns, such as soil erosion, deterioration of the physical, chemical, and biological or economic properties of soil, and long-term loss of natural vegetation. All of these processes lead to significant loss of biomass and soil organic carbon and imply a strong connection between the desertification processes and climate change affecting both desert regions and vast neighboring areas.

The UNEP estimations show that almost $20 \%$ of susceptible deserts and semideserts experience soil degradation (UNEP 1997). According to the UNEP estimations, Asia possesses the largest land area affected by desertification, $71 \%$ of which is moderately to severely degraded. For Latin America, this proportion is $75 \%$. In Africa, two-thirds of which is desert or drylands, $73 \%$ of the agricultural drylands are moderately to severely degraded (UNCCD 2001). Africa, with a rate of disappearance of forest cover of $(3.7-5) \times 10^{6}$ ha per year bearing down on both surface and groundwater resources and with half the continent's farmland suffering from soil degradation and erosion, is under the greatest desertification threat. Land-use and land-cover changes caused by desertification can seriously modify surface albedo, as well as water exchange and nutrient cycles that might have potential impact on climatic system both at the regional and global scales.

Except for the oases with intensive irrigated agriculture, the most important human influences on the desert and semideserts biomes are those connected with grazing. The effects of grazing by domestic animals on vegetation and soils are thought to be different from those of the wild herds that preceded them. Domesticated herds move slowly and do not stray great distances from watering places (Le Houérou 1989; Dregne and Chou 1992). They have an intensive impact on the pasture around the watering places, whereas the areas further away remain almost undisturbed. The result is a concentric pattern around watering places, with increasingly degraded vegetation as one approaches the center. Close to the water hole itself, where the animals remain the longest, there is no vegetation at all, and the soil is overfertilized by animal excrement. The negative effect of this overfertilization on plant growth remains noticeable for many years after watering places have been abandoned. The destruction of plant cover in intensively grazed areas often leads to the formation of dune fields and chains. The "natural" vegetation cover typical for this zone may be found only at a distance of several miles from the well. As a result of overgrazing, the widespread weed Peganum harmala (Zygophyllaceae) becomes dominant on loamy soil of Irano-Turanian deserts. It can also be found around watering places as far as west as the Ebro Basin in Spain (Walter and Box, 1983). In semidesert areas of Kazakhstan and Uzbekistan, the perennial grasses disappear from the vegetation cover under grazing pressure by domesticated herds while the number of annuals and biennials, especially Poa bulbosa var. vivipara, increases (Lioubimtseva and Adams 2002).

Conversion of semideserts and dry steppes into croplands and pastures often leads to significant carbon losses in these ecosystems. A 30-year study of carbon balance in the semi desert soils of Kazakhstan indicated a $25-30 \%$ reduction of the soil organic matter due to cultivation (Kharin and others 1999). A 30-35\% loss of soil organic carbon from the top $20 \mathrm{~cm}$ level was observed by Chuulun and others (1999) in the dry steppes of Mongolia and Inner Mongolia. Overgrazing is the main reason for the plant biomass and productivity decreases in these regions. For example, in Mongolia, the plant productivity of semidesert pastures decreases from one-third to one-half during less than half a century (Chuulun and others 1999). $\mathrm{C}_{4}$ plant cover increased while the species diversity decreased all over the Mongolian semiarid zone.

In the southwestern United States, overgrazing and trampling by livestock has caused the encroachment of woody species (Prosopis spp.) into grasslands in New Mexico (Lal 2001). Soil and vegetation degradation processes decrease net primary productivity of vegetation cover, reduce the amount of biomass, and deplete the soil carbon pool. Lal and others (1999) assumed that land degradation in the arid regions may lead to an average reduction in the soil organic carbon pool by 8-12 tons of carbon per hectare. Figure 4 summarizes some of the effects of land use on soil and vegetation carbon in arid zones.

Grazing, however, can exert both positive and negative effects on total vegetation cover, and, by implication, soil organic carbon (which is derived from plant material). Positive effects involve a slight loosening of the soil surface, facilitation of seed germination by plants and the pressing of seeds into the soil under foot, and fertilization of the soil through excrement. These positive effects are noticeable only at an intermediate grazing intensity. The experiments conducted in Repetec Biosphere Reserve in Turkmenistan showed that a medium occupancy of 0.7 sheep or goat or 0.3 


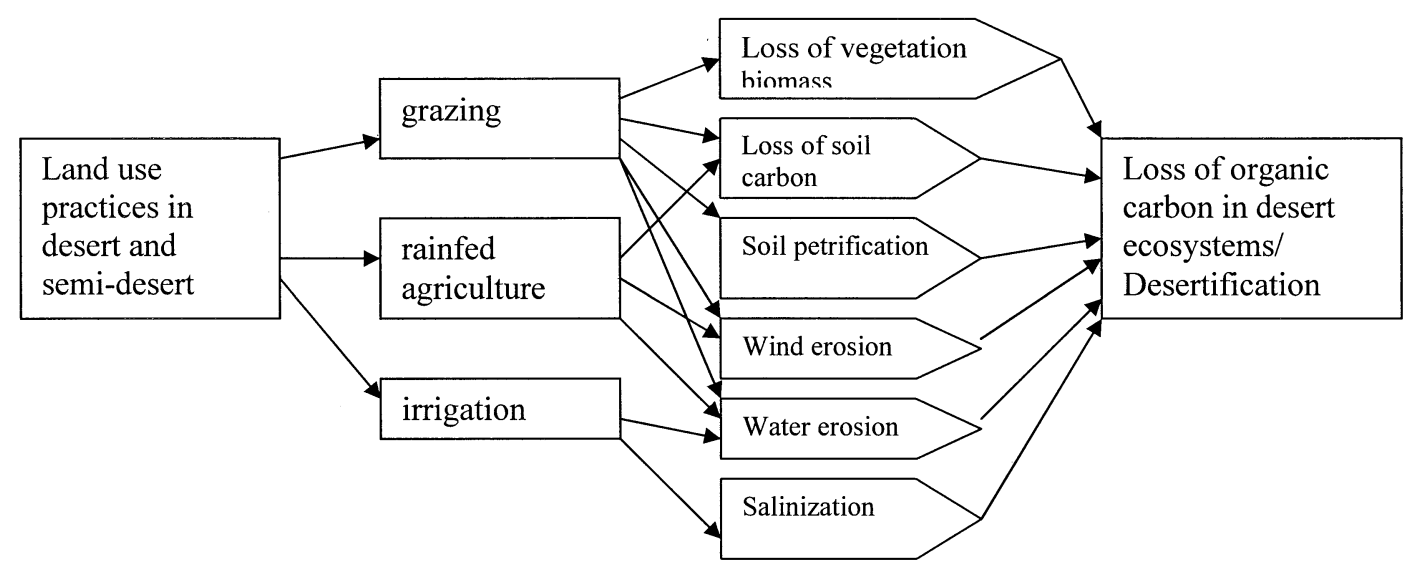

Figure 4. Global and local effects of land use on soil and vegetation carbon in arid zones.

camel per hectare of desert pastures combined with a correct rotation of grazing seasons proved to give the best results in terms of promoting vegetation cover (Lioubimtseva and Adams 2002). Grazing the same area twice in the spring has proven to be very damaging, especially when it is done every year, as it is often the case. The pastures become degraded after only 2 or 3 years. With heterogeneous pastures, the rotation must be adapted to the particular local conditions. Under rational use with moderate occupancy, optimal utilization could be sustained without damaging the plant and soil cover of the pastures. A short period of grazing during each season most closely resembles the original use by wild herds, which never remained for very long in any one place. On the other hand, with the almost total extinction of natural ungulate fauna in this area, a complete protection of the grazing field would not have a positive effect on overall vegetation cover because annual grasses or moss gradually replace the sparser natural perennial vegetation, and the surface becomes more compacted.

An important factor to be considered in the responsiveness of deserts to climate and/or land-use changes is the slow rate of development of "desert crusts," consisting of algae binding together the grains of the surface layer on loose substrates. Because of such slow recolonization of soil surfaces by the different algal crust components, underlying soils are left vulnerable to both wind and water erosion for at least 20 years after disturbance (Belnap 1995). Because soils may take 5000-10,000 years to form in arid areas such as in southern Utah (Webb and Wilshire 1983), accelerated soil loss may be considered irreversible. Loss of soil also means loss of site fertility through loss of organic matter, fine soil particles, nutrients, and microbial populations in soils. Moving sediments further destabilize ad- joining areas by burying adjacent crusts, leading to the death of their constituent micro-organisms, or by providing material for "sandblasting" nearby surfaces, thus increasing wind erosion rates. On newly disturbed surfaces, mosses and lichens often have extremely slow colonization and growth rates. Assuming that adjoining soils are stable and that rainfall is average, recovery rates for lichen cover in southern Utah have been most recently estimated at a minimum of 45 years, and recovery of moss cover was estimated at 250 years (Belnap 1995).

The effects of the anthropogenic grazing regime on soil organic carbon in arid ecosystems are complex, with the direction of influence varying from one place to another. Moderate and rationally managed grazing generally favors sequestration of organic carbon in soils both directly (organic matter from excrement) and indirectly (preserving perennial grasses such as Carex physodes, with well-developed root systems and high underground biomass).

\section{Conclusions}

Deserts are not a major store of organic carbon in either soils or vegetation. GCMs do not generally predict dramatic changes in deserts under global warming. Nevertheless, if desert regions do become significantly moister under global warming (as they did during the Last Interglacial and the Holocene Optimum) they have potential to take up hundreds of gigaton $(\mathrm{Gt})$ of carbon in more organic-rich soils and vegetation.

There is still a widespread misconception among carbon cycle modelers that desert and semidesert soils tend to be rich in organic carbon, rivaling woodland or even forest regions in terms of soil carbon storage. This is due to sampling biases and misassignment of data 
points that, in fact, fall in moister regions such as a steppe. However, although they are poor in organic carbon, desert soils are often rich in inorganic carbon, as calcrete. If this weathers under moister climate conditions in the future, it may represent a significant sustained sink of $\mathrm{CO}_{2}$ from the atmosphere.

Deserts and semideserts are widely expected to be highly responsive to increased $\mathrm{CO}_{2}$ because they are water limited and thus, in theory, responsive to the effects of $\mathrm{CO}_{2}$ on water balance. There are few results from direct $\mathrm{CO}_{2}$ fertilization experiments in deserts, but those available suggest that desert shrubs might indeed respond strongly, although there are variations. Certain ruderal species which take advantage of temporary moist phases or wet seasons may be able to respond especially strongly to raised $\mathrm{CO}_{2}$.

It is generally assumed that as $\mathrm{CO}_{2}$ levels increase, $\mathrm{C}_{4}$ plants will respond less than $\mathrm{C}_{3}$ plants in arid systems and lose out in competition. Although experiments with $\mathrm{C}_{3}$ or $\mathrm{C}_{4}$ plants grown in isolation or in competition-planted chambers support the view that $\mathrm{C}_{4}$ plants are less responsive, in (possibly) more realistic experiments of intact grassland communities, $\mathrm{C}_{4}$ plants unexpectedly show about the same or even more $\mathrm{CO}_{2}$ response than $\mathrm{C}_{3}$ species. Whether this would also be the case in desert communities is unknown.

The results of GCMs in relation to deserts in a future "greenhouse effect" climate are complex and contradictory. In general, it appears that desert areas will get slightly moister on average, although not dramatically so. Some desert areas are predicted to get drier according to some models, and wetter according to others. Hopefully, the results of a new generation of GCMs incorporating coupled ocean and land circulation and land surface feedbacks and dust flux effects will give a more consistent and realistic picture.

Dramatic changes in desert extent in the past tens of thousands of years suggest that deserts might be able to respond more strongly to global warming than the GCMs predict. It is difficult to know, however, whether there are any valid analogs between the climate changes of the past and future climate change induced by greenhouse gases.

Local and regional human impact in the marginal areas around the deserts (semiarid and subhumid grassland and savanna) have at least some potential impact on the climatic system. Desertification can significantly modify surface albedo, as well as water-exchange and nutrient cycles that might have potential impact on the climatic system both at the regional and global scales. On the other hand, improved management techniques can increase the carbon sequestration capacity of semidesert rangelands and arable lands. This, however, might require significant investments and does not seem realistic in many arid and semiarid regions of the world where the primary concern is still food security and not carbon sequestration.

\section{Acknowledgements}

We are thankful to Dr. Rattan Lal, Dr. John Kimble, and Dr. Roy Cole whose helpful comments allowed us substantially improve the earlier version of this manuscript.

\section{References}

Abell, P., P. Hoelzmann, and H.-J. Pachur. 1996. Stable isotope ratios of gastropod shells and carbonate sediments of NW Sudan as palaeoclimatic indicators. Palaeoecology of Africa 24:33-52.

Adams, J. M., and H. Faure. 1998. A new estimate of changing carbon storage on land since the last glacial maximum, based on global land ecosystem reconstruction. Global and Planetary Change 16:3-24.

Adams, J. M., and E. Lioubimtseva. 2002. Some key uncertainties in the global distribution of soil and peat carbon. Pages 459-469 in J. M. Kimble, R. Lal, and R. F. Follett. Eds, Agricultural practices and policies for carbon sequestration in soil. CRC Press Lewis Publishers, Boca Raton, Florida.

Adams, J. M., and W. M. Post. 1999. An estimate of the changing size of the caliche carbonate reservoir on land since the Last Glacial Maximum. Global and Planetary Change $20(4): 243-256$.

Adams, J. M., M. Maslin, and E. Thomas. 1999. Sudden climate transitions during the Quaternary. Progress in Physical Geography 23:1-36.

Ajtay, G. L., P. Ketner, and P. Duvigneaud. 1979. Terrestrial primary production and phytomass. Pages 129-182 in B. Bolin, E. T. Degens, S. Kempe, and P. Ketner. Eds, The global carbon cycle. SCOPE 13. Gresham Press, Surrey.

Bachelet, D., R. P. Neilson, J. M. Lenihan, and R. Drapek. 2001. Climatic change effects on vegetation distribution and carbon budget in the United States. Ecosystems 4:164-185.

Barnola, J. M., P. Pimienta, D. Raynaud, and Y. S. Korotkevich. 1991. $\mathrm{CO}_{2}$-climate relationship as deduced from the Vostok ice core. Tellus 43(B):83-90.

Batjes, N. H., and W. G. Sombroeck. 1997. Possibilities for carbon sequestration in tropical and subtropical soils. Global Change Biology 3:161-173.

BassiriRad, H., J. F. Reynolds, R. A. Virginia, and M. H. Brunelle. Growth and root $\mathrm{NO}^{-}$and $\mathrm{PO}^{3-}{ }^{3-}$ uptake capacity of three desert species in response to atmospheric $\mathrm{CO}_{2}$ enrichment. Australian Journal of Plant Physiology 24:353-358.

Bazazz, F. A. 1990. The response of natural ecosystems to the rising global $\mathrm{CO}_{2}$ levels. Annual Review of Ecology and Systematics 21:167-196.

Bazzaz, F. A., and K. Garbutt. 1988. The Response of annuals 
in competitive neighborhoods: Effects of elevated $\mathrm{CO}_{2}$.. Ecology 69:937-946.

Bazilevich N. I. 1995. Biomass and biologic production of vegetation formations of the former USSR (Biomassa i bioproductivnost rastitelnih formatsij. Nauka, Moscow (in Russian).

Belnap, J. 1993. Recovery rates of cryptobiotic crusts: Inoculant use and assessment methods. Great Basin Naturalist 53:89-95.

Belnap, J. 1995. Surface disturbances: Their role in accelerating desertification. Environmental Monitoring and Assessment 37:39-57.

Bonnefille, R., J. C. Roeland, and J. Guiot. 1990. Temperature and rainfall estimates for the past 40,000 years in Equatorial Africa. Nature 346:347-349.

Chuulun T., Ojima D. Dashordrj J. 1999. Land use change on the Mongolian steppes, Page 73 in Open meeting on the human dimensions of global environmental change research community, Shonan Village, Kanagava, Japan,24-26 June.

Ciais, P., P. P. Tans, M. Troiler, J. W. C. White, and R. J. Francey. 1995. A large northern hemispheric terrestrial $\mathrm{CO}_{2}$ sink indicated by the $13 \mathrm{C} / 12 \mathrm{C}$ ratio of atmospheric $\mathrm{CO}_{2}$. Science 269:1098-1102.

Claussen, M., C. Kubatzki, V. Brovkin, A. Ganopolski, P. Hoelzmann, and H. -J. Pachur. 1999. Simulation of an abrupt change in Saharan vegetation in the mid-Holocene. Geophysical Research Letters 26(14):2037-2040.

Coude-Goussen G. 1991. Les poussieres Sahariennes (cycle sedimentaire et place dans les environnements desertiques). Paris, Universites francophones, $480 \mathrm{pp}$.

Dregne, H. E., and Chou Nan-Ting. 1992. Global desertification dimensions and costs. in H. E. Dregne Eds, Degradation and restoration of arid lands. Texas Technical University, Lubbock, Texas.

Gladishev, A. I., and L. E. Rodin. 1977. Structure and distribution of phytomass of riverbed forest communities along the middle stretch of the River Amu-Daria (TurkmenianSSR). Botanic Journal (Botanicheskij Zurnal) 62:3-14, (in Russian).

Grünzweig, J., and Ch. Körner. 2000. Growth and reproductive responses to elevated $\mathrm{CO}_{2}$ in wild cereals of the northern Negev of Israel. Global Change Biology 6:631-638.

Guieu C. Loye-Pilot M. -D. Ridame C. Thomas C. 2002. Chemical characterization of the Saharan dust end-member: Some biogeochemical implications for the western Mediterranean Sea. Journal of Geophysical Research, 107: No D15 10.1029/2001JD000582.

Hamerlynck, E. P., T. E. Huxman, R. S. Nowak, S. Redar, M. E. Loik, D. N. Jordan, S. F. Zitzer, J. S. Coleman, J. R. Seeman, and S. D. Smith. 2000. Photosynthetic responses of Larrea tridentata to a step-increase in atmospheric $\mathrm{CO}_{2}$ at the Nevada Desert FACE Facility. Journal of Arid Environments 44:425-436.

Hulme, M. 1999. Global warming. Progress in Physical Geography 23(2):303-311.

Hulme, M., J. F. B. Mitchell, W. Ingram, T. C. Johns, J. A. Lowe, M. G. New, and D. Viner. 2000. Climate change scenarios for global impacts studies. Global Environmental Change 9:S3-S19.
Hulme, M., R. Doherty, T. Ngara, M. New, and D. Lister. 2001. African climate change: 1900-2100. Climate Research 17:145-168.

Hunt, H. W., and E. T. Elliot. 1996. Responses of $\mathrm{a} \mathrm{C}_{3}$ and $\mathrm{C}_{4}$ perennial grass steppe to elevated $\mathrm{CO}_{2}$.. Global Change Biology 2:35-47.

Huxman, T. E., and S. D. Smith. 2001. Photosynthesis in an invasive grass and native forb at elevated $\mathrm{CO}_{2}$ during an $\mathrm{El}$ Niño year in the Mojave Desert. Oecologia 128:193-201.

Huxman, E. P., R. S. Nowak, S. Redar, M. E. Loik, D. N. Jordan, S. F. Zitzer, J. S. Coleman, J. R. Seeman, and S. D. Smith. 2000. Photosynthetic responses of Larrea tridentata to a step-increase in atmospheric $\mathrm{CO}_{2}$ at the Nevada Desert FACE Facility. Journal of Arid Environments 44:425-436.

IPCC. 1995. Climate change: The science of climate change. Contribution of Working Group I to the Second Assessment Report of the Intergovernmental Panel on Climate Change. in J.T. Houghton, L.G. Meira Filho, B.A. Callander, N. Harris, A. Kattenberg and K. Maskell (eds.). Cambridge University Press, Cambridge.

IPCC. 2001. Climate change: The scientific basis contribution of Working Group I to the Third Assessment Report of the Intergovernmental Panel on Climate Change (IPCC). in J. T. Houghton, Y. Ding, D.J. Griggs, M. Noguer, P. J. van der Linden, D. Xiaosu (eds.). Cambridge University Press, Cambridge.

Kattenberg, A., F. Giorgi, H. Grassl, G.A. Meehl, G. F. B. Mitchell, R. J. Stouffler, T. Takioka, A. J. Weaver, and T. M. L. Wigley. 1996. Climate models-Projections of future climates. Pages 285-357 in J. T. Houghton, L. G. Meira Filho, B. A. Callander, N. Harris, A. Kattenberg, and K. Maskell. Eds, Climate change 1995: The science of climate change. Contribution to Working Group 1 to the Second Assessment Report of the Intergovernmental Panel on Climatic Change. Cambridge University Press, Cambridge.

Keeling, C. D., J. F. S. Chin, and T. P. Whorf. 1996. Increased activity of northern vegetation inferred from atmospheric $\mathrm{CO}_{2}$ measurements. Nature 382:146-149.

Kharin N. G., Tateishi R., Harahshesh H. 1999. Degradation of the drylands of Asia. Center for Environmental Remote Sensing (CEReS), Chiba University.

Korner, Ch. 1995. Towards a better experimental basis for upscaling plant responses to elevated $\mathrm{CO}_{2}$ and climate warming. Plant Cell and Environment 18:1101-1110.

Kotwicky, V., and R. Allan. 1998. La Niña de AustraliaContemporary and palaeohydrology of Lake Eyre. Palaeogeography, Palaeoclimatology, Palaeoecology 144:265-280.

Lal, R., H. M. Hassan, and J. Dumanski. 1999. Desertification control to sequester carbon and mitigate the greenhouse effect. in N. Rosenberg, and R. C. Izaurralde. Eds, Carbon sequestration in soils: Science, monitoring and beyond. Malone Battelle Press, Columbus, Ohio.

Lal, R. 2000. Soil erosion and carbon dynamics on grazing lands. Pages 231-247 in R. F. Follett, J. M. Kimble, and R. Lal. Eds, The potential of U.S. grazing lands to sequester carbon and mitigate the greenhouse effect. CRC/Lewis Publishers, Boca Raton, Florida.

Le Houérou, H. N. 1989. The grazing land ecosystems of the African Sahel. Springer- Verlag, Heidelberg. 
Lioubimtseva, E. 1999. Impacts of climatic changes on carbon storage variations in African and Asian deserts. . Pages 561-576 in R. Lal, J. Kimble, R. Follet, and B. Stewart. Eds, Soil processes and the carbon cycle. CRC/Lewis Publishers, Boca Raton, Florida.

Lioubimtseva, E., and J. M. Adams. 2002. Carbon content in desert and semidesert soils in Central Asia. . Pages 409-456 in J. M. Kimble, R. Lal, and R. F. Follett. Eds, Agricultural practices and policies for carbon sequestration in soil. CRC/ Lewis Publishers, Boca Raton, Florida.

Lioubimtseva, E., B. Simon, H. Faure, and J. M. Adams. 1998. Impacts of climatic change on carbon storage in the Sahara-Gobi desert belt since the Late Glacial Maximum. Global and Planetary Change 16-17:95-105.

Liu, T., Z. Guo, J. Liou, J. Han, Z. Ding, Z. Gu, and N. Wu. 1995. Variations of Eastern Asian monsoon over the last climatic cycle. Bulletin Societe Geologigue France 166(2):221-230.

Melillo, J. M., A. D. McGuire, D. W. Kicklighter, B. Moore III, C. J. Vorosmarty, and A. L. Schloss. 1993. Global climatic change and terrestrial net primary production. Nature 363:234-240.

Miller, R., and I. Tegen. 1998. Climate response to mineral dust aerosols. Journal of Climate 11:3247-3267.

Mudelsee, M. 2001. The phase relations among atmospheric $\mathrm{CO}_{2}$ content, temperature and global ice volume over the past 420 ka. Quaternary Science Reviews 20:583-589.

Nanson, G. C., D. M. Price, and S. A. Short. 1992. Wetting and drying of Australia over the past 300 ka. Geology 20:791-794.

Nechaeva, N. T. (ed). 1984. Resursy biosphery pustin Srednei Azii i Kazakhstana (Biosphere resources of deserts in Central Asia and Kazakhstan). Nauka, Moscow (in Russian).

New, M., M. Hulme, and P. D. Z Jones. 2000. Representing twentieth century space-time climate variability. Part 2: Development of 1901-96 monthly grids of terrestrial surface climate. Journal of Climate 13:2217-2238.

Oberlander, T. M. 1994. Global deserts: a geomorphic comparison. . Pages 13-35 in A. D. Abrahams, and A. J. Parsons. Eds, Geomorphology of desert environments. Chapman \& Hall, London.

Olson, J. S., J. A. Watts, and L. J. Allison. 1985. Major world ecosystem complexes ranked by carbon in live vegetation. NDP017. Carbon Dioxide Information Center, Oak Ridge National Laboratory, Oak Ridge, Tennessee.

Olson, J. S., J. A. Watts, and L. J. Allison. 1983. Carbon in live vegetation of major world ecosystems. ORNL-5862, ESD Pub. No. 1997. Oak Ridge National Laboratory, Oak Ridge, Tennessee.

Owensby, C. E. 1993. Biomass production in a tallgrass prairie ecosystem exposed to ambient and elevated $\mathrm{CO}_{2}$.. Ecological Applications 3:644-653.

Petit-Maire, N., and Z. Guo. 1996. Mise en evidence de variations climatique holocenes rapides, en phase dans les deserts actuels de Chine et du Nord de l'Afrique. Science de la Terre et des Planetes 322:847-851.

Petit-Maire, N., and Z. T. Guo. 1998. Mid-Holocene climatic change and man in the present-day Sahara desert. Pages 351-356 in A. S. Alsharhan, K. W. Glennie, G. L. Whittle, and C. G. St. C. Kendall. Eds, Quaternary deserts and climatic change. A.A. Balkema, Rotterdam.

Poorter, H., and M. Perez-Soba. 2001. Growth response of plants to elevated $\mathrm{CO}_{2}$ under sub-optimal environmental conditions. Oecologia 129:1-20.

Post, W. M., W. R. Emmanuel, P. J. Zinke, and A. G. Stagenberg. 1982. Soil carbon pools and world life zones. Nature 346:48-51.

Rognon, P. 1987. Late quaternary climatic reconstruction for the Maghreb (North Africa). Palaeogeography, Palaeoclimatology, Palaeoecology 58:11-34.

Rustamov, I. G. 1994. Vegetation of the Deserts of Turkmenistan. Pages 77-104 in V. Fet, and K. I. Atamuradov. Eds, Biogeography and ecology of Turkmenistan. Kluwer Academic, Amsterdam.

Sanlaville, P. 1992. Sciences de la terre et archéologie: L'évolution de la Basse Mésopotamie à l'Holocène.in Miskovsky, J. C. Les applications de la géologie à la connaissance de l'environnement de l'homme. Bulletin de la Société Géologique de France 160: 11-18.

Schlesinger, W. H. 1990. Evidence from chronosequence studies for a low carbon storage potential of soils. Nature 348:232-234.

Schlesinger, W. H. 1995. An overview of the carbon cycle. in R. Lal, J. Kimble, E. Levine, and B. A. Stewart. Eds, Soils and global change. CRC/Lewis Publishers, Boca Raton, Florida.

Smith, S. D., T. F. Huxman, S. F. Zitzer, T. N. Charlet, D. C. Housman, J. S. Coleman, L. K. Fenstermaker, J. R. Seemann, and R. S. Nowak. 2000. Elevated $\mathrm{CO}_{2}$ increases productivity and invasive species success in an arid ecosystem. Nature 408:79-82.

Street-Perrot, F. A., J. F. B. Mitchell, D. S. Marchand, and J. S. Brunner. 1990. Milankovitch and albedo forcing of the tropical monsoon: a comparison of geological evidence and numerical simulations for $9000 \mathrm{yrs}$. BP. Transactions of the Royal Society of Edinburg (Earth Science) 81:407-427.

Tarasov, 1992: Evlutsia klimata i landshaftov Severnogo i centralnogo Kazakhstana (Climatic and landscape evolution of northern and central Kazakhstan), Ph.D. thesis, Moscow State University Moscow, 120 pp. (in Russian).

Thompson, R. S., C. Whitlock, P. J. Bartlein, S. P. Harrison, and W. G. Spaulding. 1993. Climatic changes in the western United States since 18,000 yr B.P. Pages 468-513 in H.E. Wright, J. Kutzbach III, F.A. Ruddiman, F.A. Street- Perrott, and P.H. Bartlein. Eds, Global climates since the Last Glacial Maximum. University of Minnesota Press, Minneapolis, Minnesota.

UNCCD. 2001. Assessment of the status of land degradation in arid, semi-arid and dry sub-humid areas; Land degradation assessment in drylands and millennium ecosystem assessment. United Nations Convention to Combat Desertification. ICCD/COP (5), Geneva.

UNEP. 1992. World atlas of desertification. N. Middleton and D. Thomas (eds.).Edward Arnold for United Nations Environmental Program, London, 69 pp.

UNEP. 1997. World atlas of desertification, 2nd ed. N. Middleton and D. Thomas (eds.). Oxford University Press for United Nations Environmental Program, Oxford, 82 pp. 
VEMAP Members (Vegetation/Ecosystem Modeling and Analysis Project). 1995. Vegetation/Ecosystem Modeling and Analysis Project: Comparing biogeography and biogeochemistry models in a continental-scale study of terrestrial ecosystem resoponses to climate change and $\mathrm{CO}_{2}$ doubling. Global Biogem. Cycles 9:407-437.

Walter, H., and E. O. Box. 1983. Temperate deserts and semi-deserts. . Pages 1-159 in I. West, and E. Neil. Eds, Ecosystems of the world, Volume 5. Elsevier, Amsterdam.

Webb, R. H., and H.G. Wilshire. 1983. Environmental effects of off-road vehicles: Impacts and management in arid regions. Springer-Verlag, New York, New York.

Whitford, W. 2002. Ecology of desert systems. Academic Press, London 343 pp.
Yan, Z. W., and N. Petit-Maire. 1994. The last $140 \mathrm{ka}$ in the Afro-Asian climatic transitional zone. Palaeogeography, Palaeoclimatology, Palaeoecology 110:217-233.

Zender C. S. Radiative Forcing by mineral dust, 1999. in Proceedings of the Workshop on Mineral Dust, 9-11 June 1999, Boulder, Colorado.

Zeng, N., J. D. Neelin, K. -M. Lau, and J. Tucker. 1999. Enhancement of interdecadal climate variability in the Sahel by vegetation interaction. Science 286:1537-1540.

Zinke, P. J., A. G. Stangenburger, W. M Post, W. R. Emmanuel, and J. S. Olson. 1984. Worldwide organic soil carbon and nitrogen data. Environmental Sciences Division, Publication No.2212. Oak Ridge National Lab/US Department of Energy, Oak Ridge, Tennessee. 